\title{
CONFLICTS, CONTESTATION AND MARGINALIZATION IN URBAN AGRICULTURE: EXPERIENCES FROM KUWADZANA EXTENSION, HARARE
}

\author{
Taru J., Basure H.S., Researchers \\ Great Zimbabwe University, Masvingo, Zimbabwe \\ E-mail: tarujosiah@gmail.com, Phone: +263 772834967
}

\begin{abstract}
This study applied Norman Long's interface analysis in capturing and understanding causes of conflicts and struggles among actors practicing urban agriculture (UA) in Kuwadzana Extension. The benefits accrued by actors engaging in UA have attracted many actors to join the activity. An increase in the number of actors involved in urban agriculture has intensified competition for land and water that are scarce. This has increased struggles and contestations among various actors involved in the practice of UA. Focus of this study was on off-plot agriculture because of its contentious nature as it is practiced outside institutional frameworks that govern and regulate farming activities, access to land and water, conflict resolution and actors' interaction. A number of actors (farmers, Kuwadzana residents, council, church members) with different lifeworlds, divergent objectives, conflicting perceptions and opposing belief systems interact at the interface. Actors possess different power bases, which are used to dispossess and marginalize other actors. Inheritance, borrowing, renting, social networks and patronage are some of the ways that mediate access to land for farmers. These ways of accessing land escalated conflicts due to continuous boundary encroachment by actors who take advantage of lack of formal institution governing the practice of UA. The study captured conflict resolution mechanisms such as mediation, litigation and conciliation that are employed to resolve disputes. The efficacy of these conflict resolution mechanisms were examined, often, these mechanisms were neither legally binding nor have institutional backing, hence, these mechanisms have a tendency to generate more disputes.
\end{abstract}

\section{KEY WORDS}

Urban agriculture; Conflicts; Contestations; Perceptions; Ideologies; Interface analysis; Access to land; Land ownership regimes; Conflict resolution mechanisms.

The study situates conflicts, its causes and conflict resolution mechanisms adopted by actors as the central point of investigation. The practice of urban agriculture (UA) in Kuwadzana Extension is considered illegal and lacks formal recognition, this lack of institutional framework to regulate UA has escalated conflict occurrence. Politics of inclusion and exclusion, differential access to land and water and 'urban territorialism' have led to deeply entrenched struggles and disputes among actors. The practice of UA is marked with conflicts due to how different actors access scarce resources (land and water) and their continuation of accessing these resources. There is increased competition among farmers themselves, and also with other residents who perceive the same resources differently. Farmers use a number of ways to access land, some access land by invading, first claim basis, inheritance or as gifts. Conflicts between farmers and Kuwadzana council occur because of clashes of interests and perceptions. The council holds environmental and urban planning concerns which make the council not fully accept the practice of urban agriculture without its prior approval. Urban farmers hold opposing and contradicting beliefs from those held by the council. Farmers are involved in conflicts with non-farming residents over foot paths, access to water in shallow wells and refuse dumping. Farmers have struggles with religious institutions over land and its significance to these different actors. Conflicts between and among actors take different forms and a number of mechanisms are used to resolve disputes that occur. Various means which range from mediation to litigations are used to resolves struggles that are encountered.

UA according to Smit et al. (1996, p.3) is "an industry that produces, processes and markets food and fuel, largely in response to the daily demands of consumers within a town... on land and water dispersed throughout the urban and peri-urban area, applying 
intensive production methods, using and reusing natural resources and urban wastes to yield a diversity of crops».

A number of researches have been conducted on urban agriculture. Most of these studies have focused on UA as a coping or livelihood strategy during economic doldrums, linking it to issues of household food security (Muzvidziwa, 1998; Chingarande, 1999 and 2009; Mbiba, 1995; Toriro, 2009). Some scholars have delved much into the practice, types of UA as well as the legality or illegality of UA (ENDA-Zimbabwe, 1996; Mbiba, 1995; Chaibva, 2001; Mushayavanhu, 2003; Makonese and Mushamba, 2005 ). Focus has also been cast on challenges faced in UA by both practitioner and local authorities (Adam, 1999; Mbiba, 1995; Mudimu, 1996; Masoka, 1997; ENDA-Zimbabwe, 1994). Moyo (1995), and Moyo and Nyoni (1992) have focused on "the land question" at national level and little attention has been paid on the 'urban land question' as land for agriculture is also at the centre of conflicts in cities and towns.

Most of these studies have also identified benefits of UA to households involved. Due to these benefits, ENDA-Zimbabwe (1995) noted that between 1990 and 1994, urban cultivation in Harare increased by 92, 6\% from 4822, 38 hectares cultivated in 1990 to 9827, 96 hectares in 1994. The increase in people practicing UA has created competition for land that is scarce while lack of proper institutional framework has made the conditions under which UA is practiced conducive for conflicts. This study was inspired by Scoones' observation that most studies on livelihoods activities tend to focus on benefits accrued from these activities, and most researchers tend to use structure- agency analyses to illustrate on how actors innovate and shape structures in the process. Such studies emphasise agency of actors in the face of constraining structures. Furthermore, structuration tends to lump people as 'actors with agency', such homogenisation of people as 'actors' tends to be silent of differential access to land, issues of marginalization and patronage which are pertinent to conflict eruption (Scoones, 2009). Structuration has diverted most researchers from issues of conflicts involved in UA. Thus, there are gaps that exist emanating from theoretical framework that inform most of these studies. The use of interface analysis for this study was a reaction to and tries to cover the analytical gap of Structuration perspectives. Bernstein et al (1992, p.24) note that to understand the dynamics and causes of conflicts in livelihood activities, researchers must question who owns what, through which means, why and who gets what? Conflicts emanate from the way livelihoods activities are structured along social differences (political identity, gender, status and age). This study aimed at revealing processes of marginalisation and dispossession, conflicts and contestations in urban agriculture as a livelihood activity.

Historical development of Urban Agriculture in Zimbabwe. The study of urban agriculture is deeply rooted in the political economy of a country, and hence situating the study, and providing a historical background is important. The colonial political economy influenced how urban areas are organized economically, and some of the policies regulating urban economic and planning activities have remained as a remnant in post-colonial Zimbabwe. Production in industries was concentrated in urban areas while other economic activities such as subsistence agriculture, hunting and livestock rearing were relegated to the rural areas. Rural areas were supposed to provide urban areas with food since urbanites were engaged in non-agricultural activities within industries.

Salisbury, now Harare, was established by the British settlers as a site for administrative purpose and as a hub for industries and commerce. According to Makonese and Mushamba (2005:9) when settlers occupied Salisbury, the settlement gradually developed into an urban settlement and agricultural activities gradually gave way to urban developments that by 1950 most urban centres had effectively taken shape. The colonial regime perceived urban space as a temporary place of work to be occupied only if labour functions were being performed. Urban houses were provided for those who were employed in colonial industries. The colonial regime enacted a variety of legislations such as Vagrancy Act, Town Pass System, and Pass Consolidation Act as a way to regulate and restrict free movement of 'loafers' into urban areas. Native Rules and Regulation Board was established to register all labour contracts monthly and to issue certificates of service to workers and jobseekers. Acceptance of workers only in towns minimized the practice of UA. 
Extensive UA was not allowed in Salisbury because the town was inhabited by workers mainly. Yoshikuni $(2006,74)$ notes that in townships only vegetables were grown at the back of the houses only. Mushayavanhu (2003) notes that agriculture remained as a relic from the past and was restricted to the growing of vegetable (tsunga, covo, rape and onions) for domestic consumption and crops in summer (maize, beans and pumpkins). This type of agriculture was small scale and incidental that the colonial government saw no environmental threat. However, the colonial government used environmental laws to restrict free practice of UA. Salisbury (Protection of Land) by-laws of 1973 and the Municipal Act Chapter 125 forbad all cultivation on municipal land that was done without council's prior approval. Crops grown without prior approval were slashed by the local government (Mushayavanhu, 2003). Before 1980 UA was subdued in scale by colonial laws that controlled its practice and influx of Africans into towns.

After independence in 1980, there was a marked rural-urban migration into erstwhile restricted areas. There was a huge influx of people into towns in search of waged employment and not all could be absorbed within the formal sector. Urbanization was not synonymous with economic prosperity or opportunities for the majority of these migrants. Most migrants failed to find employment in factories and industries. Some migrants were pushed into the informal economy to eke out a living within urban areas. These migrants started to engage in petty trading, vending and some chose UA to subsidize their subsistence. Adam (1994) UA was practiced by a number of people that in 1985 the then Minister of Local Government and Town Planning Mr. E Chikowore gave a directive to local authorities to allow the establishment of Urban Agricultural Co-operatives. These cooperatives were supposed to work closely with city council. The council would lease land for UA to these co-operatives and offer extension services and to teach farmers to practice land conservation (Adam, 1994). However, these co-operatives failed and since then, no other formal institution has been formed to regulate and control access to land for UA. The introduction and implementation of ESAP in the 1990s witnessed a relaxation on the enforcement of by-laws governing the practice of UA. Due to the adverse effects of ESAP, multiple factors came into play as rationale for engaging in UA (retrenchment, drastic reduction in disposal incomes, removal of subsidies on most social services and food staffs, ineffective agricultural policies, crippled food distribution systems, unemployment, lax urban regulations, droughts of 1992-4). Due to this, government allowed those in urban areas to grow food crops to cushion themselves. ESAP has been associated with the increase in uncontrolled sprawling of UA. (Chingarande, 1999, Chingarande, 2009, p.7).

In 1997 the local government slashed some crops cultivated on public land. This period was marked by overt conflict between urban farmers and the city council. After 2002 drought and the economic meltdown that saw inflation rate shooting above $8000 \%$ (December 2007 figures) the government has zigzagged on policies that govern the practice of UA. Harare Combination Master Plans makes provision for urban farming in designated zones (City of Harare, 1992), while Nyanga Declaration on Urban and Peri-urban Agriculture (2002) aims to formalize UA, however, both the central and local governments have done little to implement these policies and laws. This has caused UA to be practiced informally without proper institutional framework, exacerbating conflicts and struggles involved in UA (Mushayavanhu, 2003).

Statement of the Problem. The benefits of UA to households has attracted more people with ENDA-Zimbabwe (1995) noting that between 1990 and 1994, urban cultivation in Harare increased by $92,6 \%$ from 4822,38 hectares in 1990 to 9827,96 hectares in 1994 . The increase in people practicing UA has created competition for land that is scarce while lack of proper institutional framework has made the environment under which UA is practiced conducive for conflicts. This study is inspired by Scoones' observation that most studies on livelihoods tend to focus on benefits accrued from the activity and most researchers tend to use structure- agency analyses to illustrate on how actors innovate and shape structures in the process. Such studies emphasise agency of actors in the face of constraining structures. Furthermore, structuration tends to lump people as actors with agency, such homogenisation of people as actors tends to be silent of differential access to land, issues of marginalization and patronage which are pertinent to conflict eruption (Scoones; 2009). Structuration has 
diverted most researchers from issues of conflict involved in UA. Thus, there are gaps that exist emanating from theoretical framework that inform most of these studies. The use of interface analysis for this study is a reaction to and tries to cover the analytical gap of Structuration perspectives. Bernstein et al $(1992 ; 24)$ note that to understand the dynamics and causes of conflict in livelihood activities, researchers must question who owns what, through which means, why and who gets what? Conflicts emanate from the way livelihoods are structured along social differences (political identity, gender, status and age). This study aims to reveal processes of marginalisation and dispossession, conflicts and contestations that have been never given prominence in most studies on urban agriculture and livelihoods. This study builds upon previous studies and aims to add to existing literature on UA.

Objectives of the study. The study sought to:

- Assess various means through which urban farmers in Kuwadzana access land and how the means increase or reduce conflict occurrence.

- Assess the various causes and nature of conflict in UA.

- Assess various ways of conflict resolution mechanism employed by the actors.

Research questions. The study aims to answer the following questions:

(a) What are the causes of conflict among actors involved in UA in Kuwadzana Extension?

(b) What power bases do actors deploy as they engage in struggles?

(c) How do farmers access land for agriculture in Kuwadzana Extension?

(e) How do these farmers resolve conflicts and disputes?

The research answers these questions by analysing how farmers access land. The means of accessing land is central to eruptions of conflict. Power bases have to be analysed as they shape how actors react, respond to actions of other actors as they interact. Lastly, the study sought to reveal how disputes and conflicts are resolved.

Theoretical framework. This study demands the use of an analytical framework that gets closest to the complexity of conflicts in UA, thus the research is informed by Actor Oriented Approach of Long (1992). Analysis is directed towards the social actors, who in this study are urban farmers, some residents of Kuwadzana Extension and the Kuwadzana district council, who have their different worldview and perceptions of what causes conflict in the practice of UA. Central to the analysis of conflict is the 'social interface' that marks intersection and interaction of actors involved in UA. Long $(1994 ; 139)$ defines the social interface as «a critical point of intersection between different social systems, fields or levels of social order where structural discontinuities, based upon differences of normative value and social interest, are most likely to be found...such discontinuities are characterized by discrepancies in values, interests, knowledge and power. Interface typically occurs at points where different and often conflicting, lifeworlds or social fields intersect or more concretely, in social situations or arenas in which interactions become oriented around problems of bridging, accommodating, segregating or contesting social, evaluative and cognitive standpoints».

Interfaces are sites of struggle and contestations as farmers, residents and council hold different and opposing ideas, beliefs and interest. Farmers are not a homogeneous group but have different and conflicting interest and perceptions amongst themselves. Farmers' interests also differ with those of non-farming residents and of the council. Thus interfaces are marked by encounters between actors with different interests, resources and power.

Methodology. This study was grounded in qualitative research methodology. The study utilized case study method. This tool involved "the study of an issue explored through one or more cases within a bounded system (i.e., a context)" ( Creswell, 2007, p.73). Unstructured interviews were used to capture case histories and to elicit authentic information on the position and action of Kuwadzana District Council towards farmers engaging in UA. Observation was used to assess how 'fields' were demarcated and the sizes of the fields.

Purposive and snowballing sampling techniques were used to recruit respondents. As noted by Long (1992) conflicts exist among people with some degree of interaction and share an interface, these techniques were instrumental in yielding a required population. For this study, twenty five farmers, fifteen non-farming respondents, ten respondents from 
churches located in the vleis and the key informant, Kuwadzana council, constitute the sample population.

Study Area. Kuwadzana Extension is found about 15 kilometres on the western part of Harare CBD. The residential area was created as a holding camp for families whose homes were demolished in preparation for the Commonwealth Conference in 1992. The area is at the outskirt of Harare on the way to Bulawayo. The area has an approximate population of 86 681 people, women constitute $52 \%$ and men the remainder (Parliament of Zimbabwe, 2009). There is a lot of undeveloped and unused land across the Harare-Bulawayo Road, which residents have turned into land for agriculture.

\section{RESULTS AND DISCUSSION}

UA and livelihoods. Several benefits were accrued from engaging in UA. Respondents noted that a good harvest can last them a whole year, thus it plays a major role in household food security. Some residents testified that through UA they had managed to raise money for paying rent and school fees for their children through selling roasted maize cobs, fresh maize and vegetables along the Harare-Bulawayo highway, at "kwaO.K" (Kuwadzana 2 shopping centre) and within the location. Hence, UA creates jobs for the unemployed especially women, and affords them a chance to generate their own cash for subsistence. Apart from supplementing households' income, UA ensures variety of diet where sweet potatoes can substitute bread while the growing of maize and vegetables has enabled farmers not to rely on shops for mealie-meal. UA also provides fresh and cheaper vegetables to Kuwadzana residence, even non-farming residents acknowledged it. For farmers there are also less transport costs when producing closer to their market. It is an important social and economic activity providing nutritious food, employment and income to a large number of people in urban areas. These associated benefits have attracted more residents into UA leading to conflicts.

Urban agriculture as a broad social interface. Long and Villarreal (1994:43) note that «Interface is a critical point of intersection between different social systems, fields or levels of social order where, structural discontinuities based upon differences... (in) social interests, are most likely to be found». Furthermore, the interface «typically occurs at points where different, and often conflicting, lifeworlds and social fields intersect. This is where multiple realities and social actors' differences are played out».

Social activities were «shaped by a multiplicity of differences, differences which may be perceived categorically but are lived relationally» (Moore; 1994,20). UA is a broader interface in which different actors interact together. There are various other sub-interfaces that constitute this broader interface. Various actors interact at different points and time and this creates a number of interfaces such as farmers - farmers interface, farmers - non-farming residents interfaces, farmers - council interface, farmers - church members interface and farmers - tenant-farmers interface. Actors interacting at interfaces use gender, age, status and political identities to mark their differences. Interface analysis entails an understanding of struggles and power differential taking place at interfaces among different actors. Scarcity of resources, differential access to resources and differing power bases make relations at the interface hostile and conflictual. Conflicts were caused by interactions of actors with differing degree of power and conflicting lifeworlds of actors.

\section{Causes of conflicts:}

(a) Scarcity of resources. Land conflicts are common and historical in Zimbabwe, and what obtains at national level cascaded down to the local level. Conflicts were an outcome of exclusion of some farmers from accessing land and water that were scarce. Various actors wanted access to resources, however, shortage of resource forced actors to compete, struggle and fight over access to land and water. Not only access to resources but unequal distribution of resources escalated struggles among actors already involved in UA. The sizes of fields were skewed, some actors had bigger fields as compared to other actors. Farmers extended their fields through shifting boundary. UA is a source of livelihoods and its importance has been discussed above. The benefits actors accrued from engaging in UA have attracted more actors join. There is no more unused land for new entrants, thus actors 
resorted to invasion of land being cultivated. Scarcity of land and access to land and water is the major cause of most conflicts and struggles in UA as also noted by Toriro (2005).

(b) Politics of inclusion and exclusions. Actors who engage in UA neither have same degree of power nor similar power bases. The concept of strategic differences is useful in understanding power difference among actors. Strategic difference refers to «areas of dissimilarity that people have among themselves, which they identify and distinguish themselves with, and which they use in negotiation over resources, as strategic weapons or tools, and to legitimate claims...» (Magadlela, 1999, p.14).

Strategic differences illustrate how actors consciously devised strategies based on their dissimilarities from other actors and used these differences in struggles over access to scarce land and water. Actors use strategic difference (social networks, political ties, being a landlord and time period one stays in Kuwadzana Extension) in specific context to access resource for farming and as weapons against other actors when conflicts erupt or during conflict resolution. Invader used their statuses as a landlord and resident of Kuwadzana to expropriate the field of a non-resident. Strategic differences were used even at negotiations as cited by respondents who used ZANU PF cell structures to resolve disputes that occurred over land. At the interface actors were regarded as agents for promoting, suppressing and negotiating their differences. Actors used these strategic differences to marginalize and dispossess fellow farmers and new comers.

Political identity. As strategies to exclude others or gain access to land, actors used their political affiliation in struggles and disputes against other farmers and non-farming residents. It is worth noting that individual identities and group identities formed part of strategic differences. Members of ZANU PF were commonly referred to as "vanhu vemusangano" (party members) by other actors, and were viewed as a group by non-ZANU PF members. Struggles and contestations were escalated by actors who used political positions within local ZANU PF structures to expropriate land from other farmers identified as non-ZANU PF. Political identity was used as a resource to mark strategic differences among actors at the interface. Some ZANU PF members gained access to land by emphasising their political identity. Those being removed from their fields resisted to a less extent because they feared being persecuted or seen as sell-outs. Some actors lost their fields because they were identified as MDC supporters. Use of political identity is not uncommon for actors to gain access to livelihoods activities (MDP-ESA, 2002). Political identities escalated struggles over access to land.

Urban territorialism. Urban territorialism is at the heart of politics of exclusion and inclusion. Territoriality in this study refers to a situation were actors have access to land for cultivation based on their area of residences. Actors residing in Kuwadzana had higher chances of accessing land than non-Kuwadzana residents. Urban territorialism mediated access to land in urban area in the same way it does in rural areas. For one to access land for farming in rural areas, one had to be a villager in that particular village (Matondi, 1999). The same practice is being used in urban areas as a strategic weapon to dispossess or alienate other actors from accessing land for UA. Actors who did not reside in Kuwadzana were not allowed to own a field in Kuwadzana by farmers that reside in Kuwadzana Extension. Since this is outside any formal framework, actors usually resisted the use of territorialism and fought to have access to land in Kuwadzana Extension. Non-Kuwadzana residents were excluded from accessing land in Kuwadzana. This caused and escalated conflicts and struggles at the interface.

This brings out conflicts at the interface emanating from territorialism as nonKuwadzana residents face stiff competition to access land in Kuwadzana. Territorial exclusion was a source of conflict in UA. As cited above in the case of an invader who used his status as a landlord and resident of Kuwadzana to expropriate land from non-Kuwadzana residents. Territoriality is a defensive strategy against other actors' access to land for UA. Strategic difference is at the centre of the analysis because social actors use these resources as the basis from which they derive their power. Some actors manipulated the social and political capital around them to their advantage and to dispossess other actors as they struggle at the interface. Urban territorialism has been used to disposes other actors from accessing land in Kuwadzana Extension. 
Group identities and status. Some actors used landlord status and concomitant long period of residing in Kuwadzana Extension as a resource to deny new tenants and nonKuwadzana residents from accessing land and water for UA. Being identified as a landlord gave some actors enough power to dispossess tenants and non-residents of Kuwadzana. Tenants noted that malendirodhi (landlords) had a habit to dispose tenants who owned fields. Tenants depended on their political ties and social networks to keep cultivating on their land. There was marked conflicts and struggles cited by respondents between landlords and tenants. The use of group identities as a strategic resource in interactions at interface distinguishes actors and also to differentiate how actors access resources. Farmers united as a group against thieves and other invaders especially non-Kuwadzana Extension residents.

There were inter-generational struggles at the interface. Landlords and older noted that the younger generations had a tendency to invade and occupy land already under use. There is no new land being opened for UA and the young generation can only access land through inheritance, donation or invasions of land claimed by someone. This caused conflicts between actors. These group identities and differences exhibited at interface are not institutionalised, thus conflicts arise from identities that are fluid.

(d) Conflicting perceptions and cosmologies. Conflicting perceptions were present at the interface due to lack of common belief system among actors engaged in UA. Conflict was caused by perceptions and ideologies which differed among actors involved, for example, on the efficacy of witchcraft. Some farmers used witchcraft to scare other farmers and residents from accessing their land, water and produces. Witchcraft was only used as a mere scare tactic by farmers to chase people away from their fields, but as a Christian she feared nothing. Whilst some actors believed in the efficacy of witchcraft, other respondents believed witchcraft was powerless and cannot harm them because they believe in Christianity, a belief system which these actors considered more powerful than witchcraft. The farmers-churches interface is marked by opposing perceptions on land. To church members, the land is sacred and holy while to farmers it was profane and has to be tilled to sustain life. Church members use prayers to counter farmers who are encroaching into their land.

Conflicting and opposing belief system and cosmologies existed among actors. Actors acted and behaved in ways that tried to portray to other actors' that their belief system was more powerful that they cannot be harmed by witchcraft. Different belief systems led to conflicts. These beliefs and perceptions shape how actors react and strategize to action of other actors. Actors who did not believe in witchcraft continued undeterred to use footpaths that cut across fields, while some actors continued to claim rights to land being cultivated by someone despites threats to punish them through witchcraft. Those who believed in the efficacy of witchcraft stopped using the footpaths or accessing water without permission because they feared the repercussions of such action. This explains why certain respondents referred to a person whose face was deformed after quarrelling with another farmer. There are conflicting lifeworlds and ideologies. For actors who believed in the traditional African culture, witchcraft was a reality and a social control mechanism. Actors who believed in other belief system such as Christianity saw witchcraft as mere scare tactics and non-existent.

(e) Perceptions of different actors on footpaths and water. Actors held conflicting beliefs on water, most farmers believe water in the shallow wells they dug was theirs to access for watering crops only because the wells were located in their respective fields. However, other farmers and residents held opposing beliefs. To some actors water was not owned and must never be monopolized by individual farmers, thus they continue accessing the water without permission. The interface between the farmers and non-farming residents is marked by clashes of interest. Farmers perceive water as water for their crops, but other actors believed the water and access to it must not be restricted as people may poison the source and injure the sole user. This is the situation on vleis and the land, farmers viewed land as for farming and as a source of livelihood. Non-farming residents perceive vleis and land as dumping area for refuse, away from their houses. The vleis from these residents' lifeworlds are the best place to dump any waste, and they dump in the fields. On paths, residents saw them as short cuts when they travel between locations. Residents believed that these paths must not be blocked because they were the shortest distance to their 
destination. Farmers held contradicting views, farmers noted that footpaths allowed other people to have easy access to their fields. As residents moved in these paths, they destroy crops and can easily steal from the fields. These differing perceptions on water, vleis and paths led to conflicts between actors. Perceptions are central to the analysis of conflict as they shape actors action. Opposing perception caused among actors, these perceptions are shaped by the actors' lifeworlds.

(f) Conflicts emanating from neo-customary practices. This study noted that informal means of accessing urban land replicate rural and pre-colonial systems of land allocation. While land was accessed through chiefs and headman in pre-colonial times, the informal land allocation system in Kuwadzana Extension can be defined as neo-customary. Rural customary practices are being re-configured in urban context, shaped by modern practice such as payment of rents. Similar phenomenon have been experienced in Bamako (Mali) by Velez-Guerra (2003) in where farmers used traditional means to access land for UA. However, in Bamako neo-customary practices were institutionalized through the chief of Bamako who controls access to land in the city. The use of customary means of accessing land, noted in the case of Kuwadzana Extension caused conflicts between farmers and tenant-farmers as land was acquired for free by these farmers who now demand tenant farmers to access land through rent paying.

Neo-customary practices represent and illustrate the adaptability of the urbanites to adapt their customs to an urban setting. Neo-customary practices were evident in urban areas, particularly in relation to access to land for UA. Neo-customary practices combine elements of customary system that were close to the people's realities and social context, while responding to ineffective governance of resources (Velez-Guerra (2003). However, neo-customary practices are not in line with the council's by-laws, which do not allow residents to use and access land for agriculture without its approval. Access to water showed that actors had opposing lifeworlds. In most rural areas access to water in boreholes, rivers and dams is not restricted in terms of access. Some actors abandoned these beliefs in urban areas where water for UA is scarce. Actors who cultivated close to the river or had wells believed the water was theirs and denied other actors access.

Farmers' means of accessing land. Ways farmers access land for urban agriculture have been discussed by a number of scholars Mubvami, Mushamba and Van Veenhuizen (2003), Chingarande (1999) and Mbiba (1995). These scholars have also noted that without any officially drawn boundaries recognized by the city authority or any formal institution, it was easy for farmers to pick quarrels over boundaries. In certain cases, one cannot even identify where exactly the boundary was located. Lack of rules to govern means of accessing land has made struggles and conflicts more pronounced. As has been shown, there was informal land allocation through social institution (social networks, political ties, inheritance), and social and political capital determined who accessed land.

(a) First claim basis. Land was accessed on the basis of making first claim to land lying idle. This was done through clearing and cultivating unused land. Clearing idle or unused land was an acceptable basis of informal land ownership. Some of the land was acquired in the early 1990s and the farmers have continued to cultivate up to date. These pioneer occupiers looked for unused land. Some of them are the initially resettled people who claimed lands when competition for land was not very sever, as noted by one respondent. With the increase in population, idle land is no longer easily available, this has led to conflicts as more and more people tried to access land that was being used. Currently this means of accessing land was associated with conflicts and squabbles since most land was already claimed.

(b) Donations and borrowing. Access to land through donations, borrowing and informal subdivision were common means through which some farmers accessed land. Land was received as gifts from relatives, friends and landlords. Those with many patches of land transferred rights to someone who became a custodian tenant or caretaker. One woman noted that she received a field from her mother-in-law. Farmers who received land this way noted that there was less competition for the land they cultivate because the land was already owned by someone, thus gaining entry had less struggles. In most cases these farmers merely received usufruct rights to the land, there were no strict conditions for 
accessing that land. There were other causes of conflicts, which were not associated with gaining access to land per se but other issues such as of thieves, access to water, implementation and tools and boundary shifting.

(c) Inheritance. Land for UA could be inherited from relatives. This mechanism, like those discussed above who received land as donations, had little problems gaining access because they were using land which already belonged to someone. However, conflicts between previous owner of land and others farmers could spill to the heirs. Conflicts over land, access to water, and boundaries were encountered by these inheritors. Those who owned nearby fields had a tendency to harass, scare and 'otherize' these new farmers; this was a source of conflict. At times, these farmers used their long history of cultivating nearby fields to reduce the size of fields by shifting the boundaries and denying them access to water.

(d) Renting. There were farmers who rented fields from those that own more than one field or cannot utilize all their land for different reasons. This type of accessing land was identified as conducive for conflict occurrence between the land owner and the tenant farmer. One respondent said: "I pay rent for this field, I don't have my own land so I look for land not in use and negotiate with the owner. I have cultivated on a number of fields...».

Obscurity of terms and conditions between these actors is verbal and open to a lot of interpretations by the actors involved. No reference was made to conflict during land acquisition, but conflict starts when these tenants start to cultivate their crops. Landowners have a tendency of claiming their fields back when they wish, or taking some produce from the tenants' field without permission. However, these tenant farmers were not immune to other causes of conflicts discussed above.

(e) Invasions and spontaneous occupations. There were individuals who claimed to have gained access to fields through invading land already being used by someone. One invader noted that: «I seized the land from a certain lady who had relocated to Kambuzuma. For two years after relocating she cultivated on her land, but I told her to look for land in Kambuzuma where she now stays. Land in Kuwadzana is for people who live in Kuwadzana, I am a landlord, she was a tenant, it made everything easy».

The whole process was marked by conflict as the actors used force to remove other actors from their land. The respondent noted that as long as you were a landlord or have strong political alignment to the ruling party, you can use these ties or status to dispossess other actors viewed as weak.

Negotiations and accommodations. Interfaces are not only marked by conflicts, there can also be accommodations and negotiations aimed at resolving the disputes. Long $(1994,139)$ noted that at interface there are «social situations or arenas in which interactions become oriented around problems of bridging, accommodating, negotiations, segregating or contesting social, evaluative and cognitive standpoints».

The interface allows for cooperation and negotiations to resolve conflicts and disputes. Though actors struggled for access to resources, they also resorted to negotiations and accommodations as a way to resolve disputes, wrangles and conflicts. The action of the council reveals accommodation at its best. The council now tolerates the practice of UA as it no longer slash or ban actors who cultivate on its land. Thus UA is now being accommodated by the council as it no longer enforces restrictive laws. Harare Municipality as a whole has changed from restrictive to a tolerant position but is yet to implement policies such as the Nyanga Declaration. However, this also shows conflict between what is on paper and what is on ground. Most by-laws do not allow the practice of UA but on ground actors are practicing UA extensively.

There is informal conciliation, mediation and negotiations that occur at the interface as actors compromise or try to have a win-win situation as they practice UA. The use of these mechanisms was important as actors aimed to resolve and reduce conflict occurrence. However, conflicts were present in these processes as actors have different power bases. At times some actors, depending on the power they weild, impose their will on other actors. This led to more conflicts as power is not a zero sum game. Group identities discussed above were not only strategic weapons during struggles but can foster negotiations and accommodations among actors as they were used as strategies for negotiating with other 
actors. Cases of actors who used political structures to solve problems and resolve conflicts were cited by respondents. Local ZANU PF politicians, cell chairperson and youth leaders were involved in resolving conflicts between actors. Strategic difference is central as it is employed both during struggles and negotiations.

When farmers were threatened by other actors such as thieves and churches, they cooperated. The case of a man who was beaten by farmers after being found stealing illustrated co-operation of farmers against outsiders. This is the case with farmers who tried to claim land back from Johanne Masowe. Farmers portray a group identity when they confronted non-farming actors such as thieves, the church or residents. This showed that not only struggles are present in UA but also co co-operation and accommodation.

\section{CONCLUSIONS}

The study established that conflicts and struggles in UA are a result of scarcity of resources that actors needed to practice UA. Scarcity of land and limited access to water is the main cause of conflicts and disputes. All other causes emanate from the scarcity of resources and perceptions of different actors. Farmers operate within an informal setting where laws are not observed and means of accessing resources are obscure. Thus, obscurity of rules and informality made the eruption conflicts more conducive.

Informality forced farmers to access land and water through social relations and social networks. The means of accessing land such as invasion, first claim basis and renting led to more conflicts because they were outside any formal arrangements. These means (inheritance, invasion, borrowing) had inherent weaknesses that led to conflicts and struggles. Without any formal arrangement, and in a situation where resources are scarce, conflicts occurred as actors cited that some actors took advantage of this informality to gain at the expense of other actors. Favouritism, greediness and egoism were rampant under this set-up, thus the means of accessing resources led to more conflicts. Actors had different interpretations and perceptions of the same thing at hand, hence this heightened conflicts and competition.

Actors tried to resolve conflicts through informal mediation and negotiations, but the informality of UA has hindered the use of legally binding agreements. Most conflict resolution mechanisms were handled by actors who had vested interests, hence this compounded the conflicts rather than resolving. Most actors sought resolution mechanisms that were retributive rather than fair. Strategic differences were employed in conflict resolution by some actors to gain at the expense of other actors. However, as aforementioned, the outcome of the conflict resolution mechanisms were not legally binding and actors continued to compete until they get a favourable outcome by their judgement. Informal ways of accessing resources are contentious and easily led to conflicts. Conflicts and struggles were more pronounced due to the informal nature of the UA, land shortage and different lifeworlds held by actors; while conflict resolution mechanisms were weakened by informality that produced decision that were not legally binding.

\section{REFERENCES}

[1] Adam, H. 1994. The social aspects of urban agriculture in Harare. Unpublished thesis (M.Sc), University of Zimbabwe.

[2] Bernstein, $\mathrm{H}$ et al. 1992. Rural Livelihoods: Crises and Responses. Oxford: Oxford University Press.

[3] Bowyer-bower, T. and Drakakis- Smith, D. 1996. The needs of the urban poor versus environmental conservation conflict in urban agriculture. London research project.ODA project R5946

[4] Brickhill, J. 2007. Investigating the Impact of Urban Agriculture in Harare, Zimbabwe. Available from: http://www.idrc.ca [Accessed 03/10/ 2010].

[5] Chaipa, I. 2001. Agriculture and the Urban Planning dilemma in Harare. Available from: http://www.ruaf.org [Accessed 09/03/ 2011]. 
[6] Chaipa, I. 2001. Institutional bottlenecks in urban poverty alleviation: The case of urban food production by the poor and the local governance system in the city of Gweru. Unpublished thesis (MPhil)

[7] Chaumba, J. Scoones, I. and Wolmer, W. 2003. "From Jambanja to Planning: The reassertion of technocracy in Land reform in Southeastern Zimbabwe." Sustainable Livelihoods in Southern Africa Research Paper 2. Brighton: IDS Sussex.

[8] Chingarande, S. D. 1999. Urban Agriculture as a Coping Strategy. A Case study of Warren Park. Unpublished thesis (M.Sc). University of Zimbabwe.

[9] Chingarande, S. D. 2009. Livelihood strategies: Contemporary urban and peri urban agriculture in Harare Zimbabwe. Unpublished thesis (PhD). University of Zimbabwe.

[10] City of Harare 1992. Harare Combination Master Plan: Study Report and Written Statement. (Unpublished Report, Department of Works) Harare

[11] Cohen, L. and Manion, I. 1994. Research Methods in Education. London: Routledge.

[12] Coser, L.A. 1968. "Conflict: Social Aspect" in Sill, D. (ed.) International Encyclopedia of Social Sciences._New York: MacMillan.

[13] ENDA-Zimbabwe 1996. Urban agriculture in Harare: Results and Recommendation of a household survey conducted in Harare. (Unpublished paper). Harare

[14] Foeken, D. 2006. To subsidise my income: Urban farming in an East-African town. Boston: Brill.

[15] Green, S. 2007. Zimbabwe land conflict. Available from: http:// www.american.edu/TED/ice/zimbabwe.html [Accessed 10/01/ 2007].

[16] Hebinick, P. and Lent, C (eds.) 2007. Livelihoods and landscapes: the people of Guquka and Koloni and their resources. Boston: Brill.

[17] Kleinman, S. Stemross, B. and McMahon, M. 1994. "Privileging fieldwork over interviews: Consequences for identity and practice", in Symbolic Interaction 17(1), pp. 37-50.

[18] Long, N. 1992. "From paradigm lost to paradigm regained? The case of an actororiented sociology of development." In Long, $\mathrm{N}$ and Long, A (eds) Battlefields of Knowledge: The interlocking of theory and practice in social research and development. London: Routledge.

[19] Long, N. and Villarreal, M. 1994. "The interweaving of knowledge and power in development interfaces" In Scoones, I. and Thompson, J. (eds) Beyond farmer first: Rural people's knowledge, agricultural research and extension practice. London: Intermediate technology Publications.

[20] Long, N. 1999. The multiple optic of interface analysis. UNESCO (working paper). Wageningen: WUA.

[21] Magadlela, D. 1999. Irrigating lives: Development interventions and dynamics of social relationships in an irrigation project. Wageningen: WUA.

[22] Makonese, M. and Mushamba, S. .2005. A Review and analysis of the policy and legislative framework for urban agriculture in Zimbabwe. Harare: MDP/ZELA.

[23] Marongwe, N. 2003. "The Fast Track Resettlement and Urban Development Nexus" in Roth, M. and Gonese, F. (eds.) (2003) Delivering Land and Securing Rural Livelihoods: Post-Independence Land Reform and Resettlement in Zimbabwe. Centre for Applied Social Sciences, University of Zimbabwe. Available from: http://www.wisc.edu/ltc/zimbabwe/zimbooktoc.html [Accessed 22/07/2011].

[24] Masoka, M. 1997. The potential role of cultivation in open space cultivation reform in Harare. Unpublished thesis ( M.A). University of Zimbabwe.

[25] Matondi, P. B. 2001. The struggle for access to land and water resources in Zimbabwe: The case of Shamva district. Doctoral thesis. Swedish University of Agricultural Sciences.

[26] Mbiba, B. 1995. Urban Agriculture in Zimbabwe: Implication for urban poverty and management. Avebury: Aldershot.

[27] Mbiba, B. 2000. Urban agriculture in Harare: between suspicion and repression. Available from: http://www.ruaf.org/index.php?q+system/files/files/Harare.PDF [Accessed 26/06/ 2009]. 
[28] Mbiba, B. 2001. The urban planning dilemma in Harare- Zimbabwe. Available from: http://www.ruaf.org [Accessed 13/07/ 2009]

[29] MDP-ESA. 2005. Policy brief on accessing land for urban agriculture by the urban poor in Harare. Harare: MDP-ESA/IDRC.

[30] Moyo, S. and Matondi, P.B. 2005. The Politics of Land Reform in Zimbabwe. (Unpublished paper).

[31] Mubvami, T. Mushamba, S. and Van Veenhuizen, R. (ed.) 2003. "Availability, access and usability of land in urban agriculture." In Urban Agriculture Magazine, 11. Available from: http://www.ruaf.org/node/342 [Accessed 19/10/ 2009].

[32] Mudimu, G. 1996. "Urban agriculture activities and women's strategies in sustaining family livelihoods in Harare, Zimbabwe." In Singapore Journal of Tropical Geography 17 (2), pp. 179- 194.

[33] Mudimu, G. et al. 2004. Improving access to land for urban and peri-urban agriculture in Harare.(Unpublished Paper.)

[34] Mushayavanhu, D. 2003. Policy brief on legislative and policy on urban agriculture in Zimbabwe. Available from: http://www.ruaf.org [Accessed 09/03/ 2009

[35] Mutonodzo, C. 2003. The social and economic implication of urban agriculture on food security in Harare-Zimbabwe. Available from: http://www.idrc.ca/es/ev-135129-201100-topic.html [Accessed 30/08/ 2009].

[36] Nuwagoba, A. 2003. Overview of urban agriculture: a Ugandan case study. Available from: http:// www.ruaf.org [Accessed 06/08/ 2009]

[37] Raftopoulos, B., and Yoshikuni, T. (ed.) 2001. Sites of Struggle: Essays in Zimbabwe's Urban History. Harare: Weaver Press.

[38] Rogerson, C. M. 1993. "Urban Agriculture in Southern Africa: Policy Issues from the International experience Development".in Southern Africa (10) 1(February 1993)

[39] RUAF. 2005. Urban food security urban agriculture a response to crisis ?Available from: http://www.ruaf.org/index.php?q=system/files/files/Urban+food+security+$+U A+$ response+to+crisis.pdf. [Accessed 07/07/ 2009].

[40] Scoones, I. 2009 "Livelihoods Perspectives and Rural Development". In The Journal of Peasant Studies. 36 (1). London: Routledge.

[41] Simmons, C.S. 2005. "Territorializing Land conflict: Place, space and contentious politics in the Brazilian Amazon". In GeoJournal (2005) 64

[42] Smit, J., Ratta, A. and Nasr, J. 1996. Urban Agriculture: Food, jobs and sustainable cities. New York: UNDP.

[43] Thompson, G. 2004. Cultivating Conflict: 'Betterment,' The Native Land husbandry Act and Ungovernability in colonial Zimbabwe: 1951-1962. in Africa Development XXIX No3. Dakar: CODESRIA.

[44] Toriro, P. 2009. "The impact of the economic meltdown on urban agriculture in Harare." in Urban Agriculture Magazine 21 (January 2009)

[45] Yoshikuni, T. 2006. African urban experiences in colonial Zimbabwe: A social history of Harare before 1925. Harare: Weaver Press.

[46] Velez-Guerra, A. 2004. Multiple Means Of Access of Land for Urban Agriculture: A Case study of Farmers' groups in Bamako, Mali. In Cities Feeding People Report Series (December 2004) IDRC. 